\title{
PENGARUH PEMBELAJARAN ONLINE TERHADAP STRES AKADEMIK SISWA DI SMA NEGERI 1 KEPANJEN
}

\author{
${ }^{1}$ Syarifatur Rofiah \\ ${ }^{1}$ SMA Negeri 1 Kepanjen, Indonesia \\ E-mail: Syarifatur@yahoo.com
}

\begin{abstract}
ABSTRAK
Perubahan pola pembelajaran terjadi di Indonesia selama wabah pandemi Covid-19.Pola pembelajaran tatap muka yang biasa dilakukan pada semua jenjang pendidikan sekolah menengah keatas, harus digantikan dengan pembelajaran online atau dalam jaringan. Penelitian ini memiliki tujuan untuk mengetahui bagaiaman pengaruh pembelajaran online terhadap stres akademik siswa pada masa pandemi covid-19. Metode penelitian yang dipilih observasional analitik dengan pendekatan cross sectional. Jumlah sampel sebanyak 285 siswa. Hasil dari penelitian menunjukkan bahwa adanya pengaruh pembelajaran online terhadap stress akademik yang dialami siswa disekolah. Pembelajaran online membutuhkan dukungan dari berbagai pihak baik pemerintah dan sekolah.
\end{abstract}

Kata Kunci:Pembelajaran Online; Stres Akademik;Siswa

\begin{abstract}
Changes in learning patterns that occurred in Indonesia during the Covid-19 pandemic outbreak. Face-to-face learning patterns carried out at all levels of secondary school education and above must be installed by online or online learning. This study aims to see how online learning affects students' academic stress during the Covid-19 pandemic. The research method chosen was analytic observational with cross sectional approach. The total sampling is 285 students. The results of the study indicate that there is an effect of online learning on academic stress in school students. Online learning requires support from various parties, both government and schools.
\end{abstract}

Keywords:Online Learning; Academic Stress; Students 


\section{PENDAHULUAN}

Masuknya corona di indoensia menjadi ancaman bagi banyak orang, virus SARS-COV2 berasal dari Wuhan Cina dan sudah banyak korban yang meninggal dunia. Dengan adanya covid-19 mengharuskan pemerintah mengambil kebijakan yang bertujuan untuk mengurangi penularan covid 19. Salah satu upaya yang diambil pemerintah adalah menetapkan PSBB (Pembatasan sosial berskala besar) di daearah yang padat penduduknya yang masuk dalam zona tidak aman. Hal ini juga mempengaruhi dunia pendidikan, dimana pemerintah memutuskan untuk meliburkan siswa dari ativitas belajar disekolah dan mulai menerapkan metode kemudian pembelajaran daring atau online.

Pembelajaran online adalah proses pembelajaran yang didukung oleh jarigan internet dan media digital yang dapat membantu menyampaikan materi pelajaran kepada siswa. Pembelajaran online menjadi solusi pada saat masa pandemi covid yang dipilih pemerintah dalam menekan jumalh korban virus corona.

Adanya virus corona di Indonesia membawa dampak pada dunia pendidikan. Sistem pembelajaran oniline saat ini menjadi alternatif sekaligus trend di era digital. Pembelajaran online yang dilaksanakan tidak secara bertemu langsung antara guru dan siswa melainkan dibantu dengan perangkat hardware yang terhubung ke jaringan internet. Melalui perangkat seperti whatsApp, telegram, zoom, meets, google classroom, maka siswa dan guru dpat melakukan proses pembelajaran online sesuai dengan jadwal akademik yang sudah ditetapkan dari sekolah (Fitriah, 2020).
Selama masa pandemi proses pembelajaran yang dilaksanakan secara online tentunya banyak mendapatkan respon dari berbagai pihak sperti orang tua, guru, dan siswa, respon dari berbagai pihak awalnya begitu positif selama proses pembelajaran tetapi dengan berjalannya waktu yang sudah begitu lama akhirnya siswa mengalami stress akademik yang disebabkan banyaknya hambatan diantaranya jaringan internet yang tidak baik, banyak siswa yang tidak memiliki cukup kuota, banyak gangguan ketika belajar di rumah seperti harus membantu orang tua, siswa merasa kurang fokus, pelajaran yang sulit diterima, minimnya persiapan yang dilakukan guru dalam menyiapkan materi pelajaran (Gunadha \& Rahmayunita, 2020; Utami et al., 2020). Adanya deadline tugas yang diberikan guru (Kompas, 2020).

Menurut penelitian dari Samsul menunjukkan bahwa selama adanya virus corona di Indonesia banyak siswa yang masih belum terbisa dengan adanya sistem pembelajaran yang baru yakni online atau dalam jaringan. Bisa dikatakan siswa masih memiliki kebiasaan yang rendah dan belum baik.

Selanjutnya penelitian Tri Nathalia Palupi, diketahui bahwa siswa SD mengalami stres selama mengikuti pembelajaran online. Hal ini bisa dilihat dari perbedaan rata-rata sebesar $2,11 \%$. Dari penelitian Tri sudah sangat jelas adanya tingkat stres pada siswa SD kelas besar.

Stress berasal dari bahasa latin yang artinya tegang atau genting, secara harfiah stress dapat didefiniskan stimulus atau situasi yang memicu emosi negatif yang menciptakan tuntutan fisik dan psikis pada 
individu dalam menghadapi ancaman (Khayat, 2007).

Selanjutnya penelitian Ade dkk menunjukkan yang mengalami stres akademik selama proses pembelajaran jarak jauh mayoritas adalah mahasiswa dengan persentase $13 \%$ (39 responden) masuk dalam kategori tinggi, 75\% (225 responden) kategori tingkat sedang dan $12 \%$ (36 responden) tingkat rendah.

Berdasarkan uraian diatas, maka dapat dijelaskan tujuan penelitian ingin mengetahui bagaimana pengaruh pembelajaran online terhadap stres akademik siswa selama masa pandemi covid-19. Penelitian dilakukan untuk mengetahui hambatan siswa dalam melaksanakan aktivitas belajar yang menyebabkan timbulnya stres akademik. berbagai hambatan dalam aktivitas belajar dapat berdampak terhadap hasil belajar siswa, sehingga perlu diadakannya evaluasi terkait hal ini sebagai tindak lanjut dari pembelajaran online, apakah bisa terus digunakan selama pandemi atau kembali diberlakukannya belajar secara tatap muka atau luring.

\section{METODE}

Jenis penelitian yang digunakan observasional analitik, penelitian ini mencari adakah hubungan antar variabel terhadap data yang dikumpulkan. Hipotesis penelitian sangat diperlukan pada penelitian observasional analitik. Desain yang digunakan dalam penelitian adalah cross sectional yaitu peneliti melakukan pengukuran variabel pada suatu subjek satu kali saja dan pengukuran dilakukan pada saat itu pula, sehingga tidak perlu dilakukan pengukuran ulang.

Sampel yang digunakan siswa SMA Negeri 1 Kepanjen dengan jumlah sebanyak 285 siswa.

Penelitian dilakukan pada saat bulan November 2020. Pada penelitian ini, peneliti membagikan kuesioner melalui google form. Isi dari kuesioner yang dibagikan ke siswa berupa informasi pembelajaran online dan stres akademik siswa. Untuk stres akademik peneliti membagikan Educational Stress Scale for Adolescent (ESSA).

Siswa diberikan kuesioner dalam bentuk pertanyaan. Beberapa pertanyaan yang terdapat pada kuesioner diantaranya dengan adanya sistem pembelajaran online apakah siswa dapat mengikuti proses pembelajaran online dengan aktif, apakah jadwal pelajaran dari sekolah sudah sesuai dengan jadwal akademik, siswa memiliki dukungan jaringan internet yang baik dan lain sebagainya. Sedangkan untuk mengukur variabel stres akademik menggunakan kuesioner Educational Stress Scale for Adolescent (ESSA), pertanyaan yang ada pada kuesioner diantaranya adalah banyaknya deadline tugas dari guru yang diberikan ke siswa, siswa dituntut dapat melakukan pembelajaran online secara mandiri, guru banyak melakukan evaluasi pembelajaran dan lain sebagainya.

Variabel bebas adalah pembelajaran online dan variabel terikat adalah stres akademik. Sampel mengunakan random sampling. Uji analisis regresi logistik dengan convidence interval $95 \%(a=0,05)$. 


\section{HASIL DAN PEMBAHASAN}

Distribusi Frekuensi Karakteristik Siswa

Tabel 1. Karakteristik Usia Siswa

\begin{tabular}{ccc}
\hline Usia & Frekuensi & Persentase (\%) \\
\hline 14 & 10 & 3,50 \\
15 & 72 & 25,26 \\
16 & 128 & 44,91 \\
17 & 75 & 26,31
\end{tabular}

Total 285 100

Sumber: Data Primer 2020

Dari tabel 1 dapat diketahui sebanyak (BKKBN ) rentang usia remaja antara 10-24 128 responden $(44,91 \%)$ berusia 16 tahun. tahun. Rentang usia 17-20 dapat dikatakan Pada urutan kedua sebanyak 26,31\% berusia 17 tahun. memiliki kematangan psikologi dan seksual

Sementara dalam program Badan serta memasuk masa remaja akhir atau remaja lanjut (Marmi, 2014).

Kependudukan dan Keluarga Berencana

Tabel 2. Karakteristik Jenis Kelamin Responden Berdasarkan Tingkat Stress Akademik Selama Pembelajaran Daring

\begin{tabular}{ccccc}
\hline $\begin{array}{c}\text { Jenis } \\
\text { Kelamin }\end{array}$ & $\begin{array}{c}\text { Stres } \\
\text { Akademik }\end{array}$ & Frekuensi & $\begin{array}{c}\text { Persentase } \\
(\%)\end{array}$ & $\begin{array}{c}\text { Total Keseluruhan } \\
\text { Responden }\end{array}$ \\
\hline Laki-laki & Ringan & 3 & 4,41 & \\
& Berat & 65 & 95,59 &
\end{tabular}

\begin{tabular}{|c|c|c|c|c|}
\hline & & 68 & 100 & Perempuan $78 \%$ \\
\hline \multirow{2}{*}{ Perempuan } & Ringan & 5 & 2,30 & \\
\hline & Berat & 212 & 97,69 & \\
\hline Total & & 217 & 100 & \\
\hline
\end{tabular}

Sumber: Data Primer 2020

Dari tabel di atas dapat dijelaskan persentase perempuan sebesar $(97,69 \%)$ bahwa tingkat stress banyak dialami oleh dan laki-laki dengan jumlah (95,59\%). perempun yakni sebanyak 217 responden (78\%). Dari jenis kelamin, perempuan memiliki tingkat stres lebih tinggi dibandingkan laki-laki dengan jumlah 
Tabel 3. Media Pembelajaran Online

\begin{tabular}{ccc}
\hline Media Pembelajaran Daring & Frekuensi & Persentase (\%) \\
\hline Grup Whatsapp & 202 & 70,87 \\
Grup Telegram & 0 & 0 \\
Zoom & 17 & 5,96 \\
Googlemeet & 9 & 3,17 \\
Google Classroom & 57 & 20 \\
Lain-lain & 0 & 0 \\
\hline Total & 285 & 100 \\
\hline
\end{tabular}

Sumber: Data Primer 2020

Dapat diketahui bahwa selama adanya virus corona, proses pembelajaran dialilhkan menjadi pembelajaran online. Aktivitas belajar dirumah yang semula menjadi hal baru, saat ini sudah menjadi kebiasaan. Beberapa media pemeblajaran online yang saat ini sering digunakan berdasarkan keterangan yang ada pada tabel 3 adalah sebagai berikut siswa banyak menggunakan aplikasi whatsapp dengan persentase 70,87\%. Aplikasi whatsapp dianggap sebagai media yang paling mudah untuk digunakan. Selain hal tersebut aplikasi whatsapp dinilai tidak memerlukan banyak kuota internet. 
Syarifatur Rofiah

Jurnal Consulenza:Jurnal Bimbingan Konseling dan Psikologi Volume 4, Nomor 1, Tahun Edisi 2021, Halaman 41-47 e-ISSN 2623-033X, p-ISSN 2623-0348

Tabel 4. Efektifitas Pembelajaran Online

\begin{tabular}{ccc}
\hline Efektifitas & Frekuensi & Persentase (\%) \\
\hline Efektif & 55 & 19,29 \\
Tidak Efektif & 230 & 80.70 \\
\hline Total & 285 & 100 \\
\hline
\end{tabular}

Sumber: Data Primer 2020

Pembelajaran online tidak terlepas dari jaringan internet. Koneksi internet yang baik tentunya menjadi sarana penting bagi proses pemebelajaran online, namun tak memungkiri hal ini juga menjadi kendala bagi banyak siswa yang tinggal di daearh pelosok atau yang sulit mendapatkan koneksi internet yang stabil. Lalu apakah pembelajaran dapat online dapat dikatakan efektif selama masa pandemi covid.

\section{Dalam tabel 4 dijelaskan bahwa} kegiatan pembelajaran secara online dikatakan tidak efektif dengan presntase 80,70\% (230 Responden) hal dikarenkan siswa kesulitan dalam mendapatkan sinyal, sulitnya memahami materi yang diberikan oleh guru, banyaknya tugas yang diberikan, jadwal belajar yang tidak terjadwal dengan baik. Disamping itu juga perlu kesadaran dan kedisiplinan dari siswa untuk mengikuti proses pembelajaran. Guru juga perlu mulai terbiasa dengan sistem pemebeljaran online, guru harus memiliki keterampilan untuk membuat media pembelajaran yang menarik.

Berdasarkan hasil uji analisis statistik regresi logistik, dikatakan signifikan adanya pengaruh pembelajaran online terhadap stres akademik siswa selama masa pandemi covid19 , dengan nilai $p$ sebesar 0.023 dimana nilai $\mathrm{p}<0,05$.

Pada penelitian Widiyono dijelaskan bahwa pembelajaran online dinilai kurang efektif untuk diberikan kepada mahasiswa, hal ini disebabkan sulitnya mahasiswa dalam memahami materi yang diberikan dan dijelaskan oleh dosen (Widiyono, 2020).
Selaras dengan penelitian sebelumnya penelitian Firman dan Rahayu menyebutkan bahwa mahasiswa menganggap pembelajaran online justru membuat mahasiswa tidak nyaman, banyak mahasiswa yang mengalami kesulitan diantaranya sulit dalam menerima materi yang diberikan dosen. Dengan hanya mengandalkan media seperti zoom atau meet tidak cukup efektif untuk dapat membaca dan memberikan penjelasan secara menyeluruh tentang materi perkuliahan (Firman \& Rahayu, 2020).

Hasil penelitian Agus dkk, menyebutkan mahasiswa menjadi terbebani dengan adanya sistem pembelajaran online dikarenakan beratnya tugas yang diberikan oleh masing-masing dosen berdampak pada tingginya tingkt stres yang dialami oleh mahasiswa dengan persentase sebesar $72 \%$ (Watnaya et al., 2020).

Sistem pembelajaran online yang sudah diterapakn selama kurang lebih 1 tahun di Indonesia tentunya membawa dampak yang beragam, mulai dari kejenuhan dalam proses pembelajaran online, bahkan sampai pada tingkat stres akademik yang dialami oleh siswa.

\section{SIMPULAN}

Pembelajaran online selama pandemi covid-19 dapat meningkatkan stres akademik siswa. Akibat dari stres akademik terjadi karena adanya sistem pembelajaran yang berubah dari tatap muka ke pembelajaran secara online dan secara cepat dimana siswa dituntut untuk memiliki kemandirian akademiknya, hal ini di nilai sebagai tolak ukur kemajuan dari hasil belajar siswa. 
Berhasilnya proses pembelajaran online tentunya tidak hanya terletak pada kesadaran dan kedisiplinan dari siswa, tetapi perlu adanya dukungan dari pemerintah dan

\section{DAFTAR PUSTAKA}

Ade CPH, Dinda PH, Samsul RH.(2020). Analisis Tingkat Stres Akademik Pada Mahasiswa Selama Pembelajaran Jarak Jauh Dimasa Covid-19. Biblio Couns : Jurnal Kajian Konseling dan Pendidikan. 10-14.DOI :https://doi.org/10.30596/bibliocouns.v3i1 .4804

Firman, F., \& Rahayu, S. (2020). Pembelajaran Online di Tengah Pandemi Covid-19. Indonesian Journal of Educational Science (IJES), 2(2), 81-89. https://doi.org/10.31605/ijes.v2i2.659

Gunadha, R., \& Rahmayunita, H. (2020). Kuliah Online saat Corona Picu Ketimpangan Akses Bagi Mahasiswa Miskin. https://www.suara.com/news/ 2020/04/16/130712/kuliah-online-saatcorona-picu-ketimpangan-akses-bagimahasiswa-miskin

Jiandong Sun, Michael P. Dunne,Xiang-yu Hou, and Ai-qiang Xu (2015). Educational Stress Scale for Adolescents:Development, Validity, and Reliability With Chinese Students. Journal of Psychoeducational Assessment $534-$ 546.DOI: $10.1177 / 0734282910394976$

Kompas. (2020). Hambatan dan Solusi Belajar dari Rumah. https://muda.kompas.id/baca/2020/04/10 hhambatan-dan-solusi-saat-belajar-daringdari-rumah/

Marmi. (2014). Kesehatan Reproduksi. Pustaka Pelajar

Samsul Rivai Harahap.(2020). Konseling: sekolah dalam menyiapkan sarana prasarana yang dapat menunjang kegiatan pembelajran online.

Kebiasaan Belajar Siswa Dimasa Pandemi Covid-19.Jurnal Pendidikan dan Konsleing.30-35

Tri palupi.(2020).Tingkat Stress pada Siswa-Siswi Sekolah Dasar dalam Menjalankan Proses Belajar Di Rumah Selama Pandemi Covid -19.JP3SDM. 1829

Watnaya, A. kusnayat, Muiz, M. hifzul, Nani Sumarni, Mansyur, A. salim, \& Zaqiah, Q. yulianti. (2020). Pengaruh Teknologi Pembelajaran Kuliah Online di Era Covid19 dan Dampak terhadap Mental Mahasiswa. EduTeach : Jurnal Edukasi Dan Teknologi Pembelajaran, 1(2), 153165.https://doi.org/10.37859/eduteach.v1i 2.1987

Widiyono, A. (2020). Efektifitas Perkuliahan Daring (Online) pada Mahasiswa PGSD di Saat Pandemi Covid 19. Jurnal Pendidikan, 8(2),169177.https://doi.org/10.36232/pe ndidikan.v8i2.45 
Syarifatur Rofiah

Jurnal Consulenza:Jurnal Bimbingan Konseling dan Psikologi

Volume 4, Nomor 1, Tahun Edisi 2021, Halaman 41-47 e-ISSN 2623-033X, p-ISSN 2623-0348 